\title{
书香溢校园 阅读润童年
}

多元解读阅读教学策略

\section{The fragrance of books overflows the campus, reading makes childhood}

-Multiple interpretation reading teaching strategies

\author{
张燕 \\ Yan Zhang \\ 安丘市锦湖小学 中国・山东 潍坊 262100 \\ Anqiu Jinhu Primary School, Weifang, Shandong, 262100, China
}

\begin{abstract}
摘 要:根据教研室要求,2015 至 2016 学年度是 “阅读能力提升年”,为此,我们学校确立了以阅读为核心的育人工程,开展 了丰富多彩的系列读书活动。在此基础上,我们六年级语文组针对学生特点, 又细化了一系列阅读措施, 下面就是我在阅读 教学策略方面的汇报。
\end{abstract}

\begin{abstract}
According to the requirements of the teaching and research section, the 2015 to 2016 academic year is the " Reading Ability Improvement Year". To this end, our school has established an education project with reading as the core and carried out a series of colorful reading activities. On this basis, our sixth grade Chinese group has refined a series of reading measures according to the characteristics of students. The following is my report on reading teaching strategies.
\end{abstract}

关键词: 阅读;教学;策略

Keywords : reading; teaching; strategy

DOI : $10.36012 /$ sde. v3i2. 2945

\section{1 深领学校阅读要求, 重视学生思想动员}

学校召开了全校师生阅读动员大会, 确立了“建设书香 校园,打造特色学校” 的目标, 提出了 “全员阅读” 的口号; 发 出了 “把书读旧, 把书读薄” 的倡议。我们把这些思想也深入 贯穿给学生, 给学生讲阅读能力就是学习能力, 六年级阅读 能力的提升,正是同学们学习长足发展的黄金时期,讲目前 社会上提倡重视语文的最流行的一句话 “得阅读者得语文， 得语文者得高考”, 以此帮助孩子认识到阅读的重要意义, 以 便养成良好的阅读习惯。

\section{2 明确师生阅读书目, 共同探讨阅读策略} \section{(见下表)。}

\begin{tabular}{c|c|c}
\hline 读书步骤 & 符号批注 & 文字批注 \\
\hline 1. 读通课文 & (圈)标在课文生字中。 & 生字扩词、成语、生词注释 \\
(写什么 $)$ & ( ) 标在课文新词中。 & 给新词找近反义词等。 \\
抎 & (1)(2) (序号)标在每一自然段前。 & 想想文章写了什么? \\
\hline
\end{tabular}

(1)课本的课文阅读:即每年级的语文课本中的课文。

(2)主题丛书的阅读:咱们全市统一的主题阅读丛书。

(3)经典名著的阅读: 如古典四大名著《西游记》《水湤 传》《三国演义》《红楼梦》。

(4)推荐书目的阅读: 从淮坊市教育局下发的读书目录中 推荐阅读。

\section{3 全组统一阅读方法,有效指导学生阅读}

例一:指导学生对课本中的课文阅读一一批注式阅读。

我们利用表格,引导学生掌握比较系统全面的阅读方法

【作者简介】张燕 (1970 ), 女, 山东安丘人, 汉族, 高级教师, 从事小学语文教学研究。 


\begin{tabular}{|c|c|c|}
\hline $\begin{array}{l}\text { 2. 读懂课文 } \\
\text { (怎样写) } \\
\text { 的预 }\end{array}$ & $\begin{array}{l}\| \text { 、 ( 分开号) 用来划分段落与层次。 } \\
\sim \sim \text { (曲线)划在文章优美语句下面。 } \\
\triangle \triangle \text { (着重号) 标在句子关键词下面。 }\end{array}$ & $\begin{array}{c}\text { 查查作者及写作背景。 } \\
\text { 理清写作顺序/写作结构 } \\
\text { 赏析佳句,记录心得。 }\end{array}$ \\
\hline $\begin{array}{l}\text { 3. 读透课文 } \\
\text { (为什么写) } \\
\text { 动动动 }\end{array}$ & $\begin{array}{c}==\text { (双横线) 划在文章关键句子 } \\
\text { (过渡句、总起句、中心句等)下面。 } \\
\text { 一 ? (疑问号) 用在有疑问的词句末尾 }\end{array}$ & $\begin{array}{l}\text { 发现疑问, 提出问题。 } \\
\text { 体会主题,获得启迪。 }\end{array}$ \\
\hline
\end{tabular}

\section{例二: 指导学生对主题学习丛书的阅读}

(1)阅读时继续运用以上符号画出每页中恰当生动的词 语、成语等。

(2)画出精彩句段,如优美语句、哲理句、典范引文、重要 段落、新䓉说法及特别值得注意的地方等等。可以批注其好 在哪里。

(3)每篇文章至少有两处批注,如对重点词语及语句的感 悟、过渡句、写作手法、首尾呼应等等,都可以根据学生自己 的阅读理解水平自主作批注。

(4)针对文章后的阅读提示进行阅读, 有启发性的问题要 结合实际事例写一写,一般要求不少于 50 字。

(5)每读一篇文章,要用几句话对本文进行简要概括, 写 在题目旁边的空白处。

(6)每周周三阅读课上精读一篇文章, 按照抄记要求做好 读书抄记。

(7)每周在日记本上写两篇读后感, 课上交流读书收获。

例三:指导学生对古典名著的阅读

每天晚上拿出 30 分钟左右时间读名著, 至少读完一回 的内容, 并明确阅读方法要求。为保证读书能落到实处, 绝 不布置机械抄写的语文作业。现以六年级读《三国演义》为 例解读。

(1)第一阶段 $1-24$ 回,并于月末检查阅读情况, 举行 一次三国小故事朗读会,并出一期读书手抄报。

(2)第二阶到第 48 回,制作三国人物资料卡。

(3)第三阶段到 72 回,复述 “赤壁之战” 的经过。并能评 论故事内容, 评选“最佳评书员”。

(4)第四阶段至 96 回, 月末举行“我知道的三国成语、歇 后语” 交流活动,举行关于曹操的辩论会。

(5)第五阶段阅读结束。写读书笔记, 可以写人物,也可 写故事。完成问卷调查。

例四: 指导学生对推荐书目的阅读

对于潍坊市阅读能力提升工程的推荐阅读目录, 我们学 校每生打印一张, 然后根据学生年级及年龄特点由各年级备 课组长牵头确定阅读篇目, 让孩子标记出来, 由家长陪同自 主购买阅读。

阅读方法同主题从书、经典名著的诵读方法基本一致。 争取让孩子养成不动笔墨不读书的好习惯。

\section{4 制定有效检查评价, 抓实学生真正阅读}

(1)课文阅读检查: 每个语文老师课堂随机检查,每课 一查。

看批注,听朗读,阅抄记。

(2)主题从书检查:语文老师每周都调度,每两周一查,与 课本单元同步。每学习一个单元, 与单元主题配套的主题丛 书就得读完,老师收起, 根据要求严格检查。对未读完的同 学与家长沟通, 由家长监督完成。

(3)组内每学期至少举行两次评比, 检查小组直接到每个 教室打分,每个学生必须把阅读书本、日记、读书抄记等摆在 自己的课桌上,这样阅读的数量、质量、读书心得、摘抄记录 一目了然! 评比结果纳入老师的量化考核,作为评先树优的 重要依据。这也是学校阅读育人工程的一项检查措施。

\section{5 开展多彩读书活动,激发学生阅读热情}

所有的阅读工程不是在教条与呆板中进行的,而是融合 在丰富多彩的活动中, 我们六年级组不折不扣地落实学校举 办的各种活动, 激发学生的读书热情, 促进学生阅读能力的 提升。

\section{6 小结}

29 名同学曾代表学校参加市级征文比赛 28 名获一等 奖, 1 名获二等奖, 还有很多学生的习作屡屡见诸报端。

学校开展的“藏书开放 全员阅读”活动在安丘电视台新 闻频道进行了跟踪报道。

路过走廊图书架、阅览室时, 经常可见学生们正捧着书 本在静静地阅读; 穿行于教室间,善于积累的孩子正圈点勾 画、奋笔疾书; 执教于课堂中,智慧的火花正四处碰撞。“最 是书香能致远”一一读书, 让孩子的人生变得绚丽多彩; 读 书, 让校园焕发出勃勃生机; 读书, 让阅读育人更加个性 鲜明!

\section{参考文献}

[1] 王琦. 小学高年段语文阅读教学中的个性化思考与实践 $[\mathrm{J}$. 语文世界, $2018,(\mathrm{Z} 2)$

[2] 吴洁敏. 利用翻转课堂提高小学高年段语文阅读教学有效性 的策略 [J. ] 新课程, 2017, (5)

[3] 任怀玲. 基于小学语文阅读教学的几点思考 [. J ] . 好家长, 2015(43)

[4] 陈先琴. 浅析如何在小学语文阅读教学中把握重难点 $[\mathrm{J}]$ 新课 程( 综版), 2018(12) 